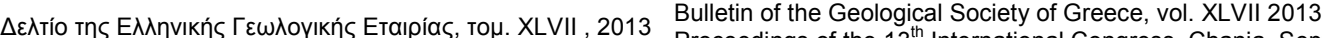

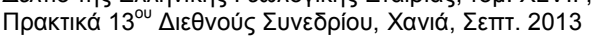
2013

\title{
SPATIO-TEMPORAL EARTHOUAKE CLUSTERING IN THE WESTERN CORINTH GULF
}

\author{
Karagianni E. ${ }^{1}$, Paradisopoulou P. ${ }^{1}$ and Karakostas V. ${ }^{1}$ \\ ${ }^{1}$ Geophysics Department, School of Geology, Aristotle University of Thessaloniki, GR54124, \\ Thessaloniki,Greece,elkarag@geo.auth.gr,ppara@geo.auth.gr,vkarak@geo.auth.gr
}

\begin{abstract}
Corinth Gulf has been studied, thoroughly using multidisciplinary approaches (geological, seismological, geodetic etc), which revealed its complicated tectonic behaviour. In the last five years or more, an intense continuous microseismic activity is observed in the westernmost part of the gulf covering the area from west of Aigio to the area west of Rio Antirrio strait, near the city of Patras. Aiming to study in detail the properties of this microseismic manifestation, the recordings of the Hellenic Unified Seismological Network (HUSN) are used to accurately determine the focal coordinates of earthquakes with magnitudes $M=1.5$ or more. Relocation was performed using the HYPOINVERSE program, for all available data for the period 2010-2011 when earthquakes up to magnitude $M=5.5$ occurred. The space time plot of the epicentres shows that seismicity is not random in the area but formed distinctive clusters, indicating an $E$-W striking seismic zone whose patches are successively activated for certain periods. The present work deals with the investigation of spatio-temporal evolution of seismicity with the intention to examine the migration of seismicity and multi-segment activation.
\end{abstract}

Key words: Seismicity relocation, migration of seismic activity, focal mechanisms.

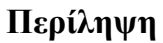

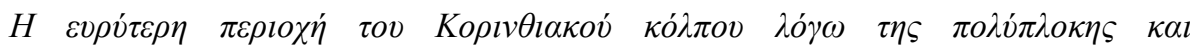

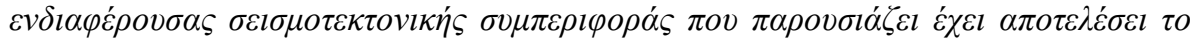

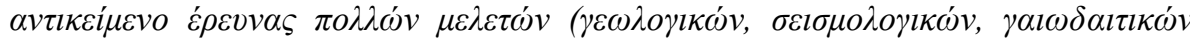

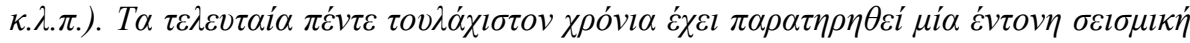

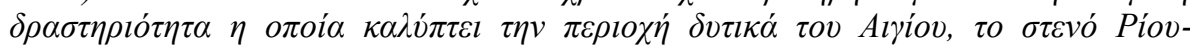

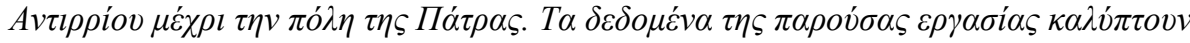

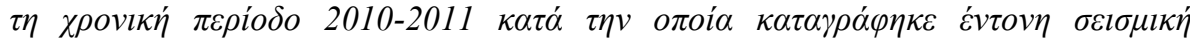

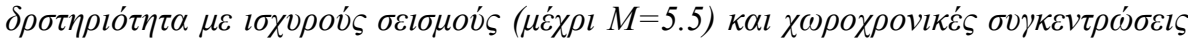

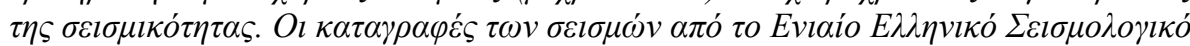

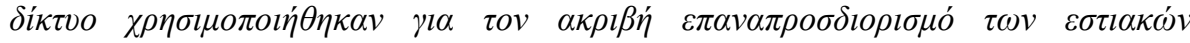

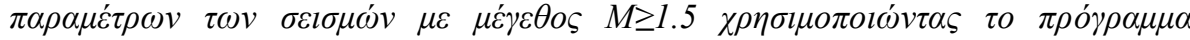

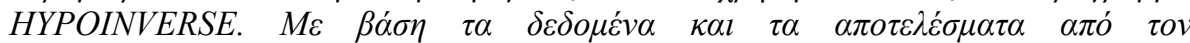

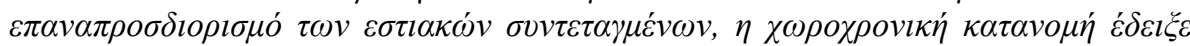

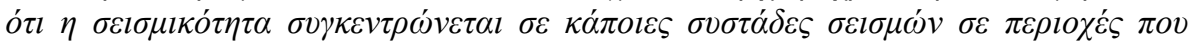

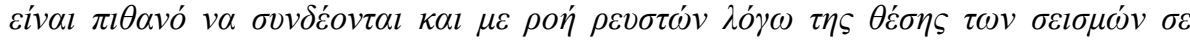

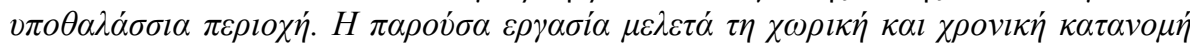

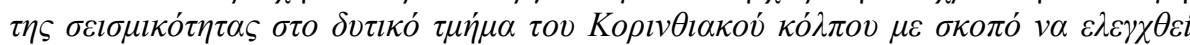

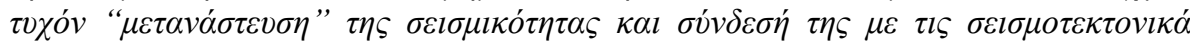
$\kappa \alpha \theta o \rho l \sigma \mu \dot{v} v \varepsilon \varsigma \pi \varepsilon \rho l o \chi \varepsilon ́ \varsigma$.

$\underline{\text { XLVII, No } 3-1109}$ 


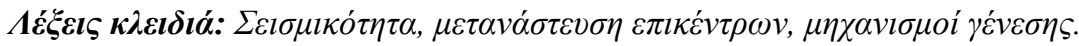

\section{Introduction}

Earthquakes are usually observed in clusters both in time and space. A significant part of these clusters is caused by the aftershock sequences of major earthquakes. However, smaller earthquakes $(\mathrm{M}<5.0)$ also generate aftershocks and at least some of the space time clustering in short time and distances is probably caused by triggering among small earthquakes. The spatial distribution of microseismicity is very useful in deciphering complicating fault structures at depth.

The Gulf of Corinth is one of the most seismically active zones in Europe (e.g. Hatzfeld et al. 2000; Burton et al. 2004). It is the fastest continental rift in the world, with the geodetically measured extension varying from $\sim 5 \mathrm{~mm} / \mathrm{yr}$ at the eastern part, to $\sim 15 \mathrm{~mm} / \mathrm{yr}$ at the western part (Briole et al., 2000; Avallone et al., 2004). The rift initiated sometime in the late Pliocene and was superimposed on the NNW-SSE trending Hellenides orogenic belt of Oligocene age. The seismicity as shown in many works is very different in the western part of the rift with the occurrence of (frequent earthquake swarms with magnitudes smaller than 4.5. The focal mechanisms show a consistent pattern of E-W trending normal faulting, with a shallow plane dipping toward the north (Baker et al. 1997). This pattern is consistent with microseismic observations obtained by dense temporary networks (Hatzfeld et al. 1990, 2000; Rigo et al. 1996) as well as with high resolution seismic reflection and multibeam bathymetric data (McNeil et al. 2005; Bell et al. 2008).

In this work, we study the spatio-temporal evolution of seismicity in the western part of Corinth gulf, trying to examine the migration of seismicity and multi-segment activation, as this later has been mentioned in previous studies (e.g. Doutsos et al., 1992; Flotte et al., 2005; Tselentis et al., 2007).

\section{Data and Location Procedure}

\subsection{Data Processing}

The recordings of P- and S- seismic waves, from the (HUSN), were used to obtain the earthquake location for the year 2011. The network in the study area is quite dense and hence the focal coordinates could be defined with considerable accuracy even for weak seismic events $(M \leq 2.0)$. In order to achieve a satisfactory hypocentral depth resolution special attention was paid to the manual S-picks and to the adequate azimuthally station coverage. Although some earthquakes of the dataset were recorded by many seismological stations, the recordings of the 27 stations in epicentral distances up to $140 \mathrm{~km}$ were used, with most of them located at distances less than $100 \mathrm{~km}$ (Figure 1). The recordings of 365 earthquakes were manually picked and merged with 724 earthquakes from Efpalio sequence (January 18, 2010-March 09, 2010) in order to capture the seismic activity evolution from 2010 (Karakostas et al., 2012). The final catalogue contains $\mathrm{M}_{\mathrm{L}}$ magnitudes (obtained from the monthly bulletins of the Geophysics Department of the Aristotle University of Thessaloniki) estimated using the formula proposed by Hutton and Boore (1987), after appropriate filtering of the data to simulate Wood Anderson recordings.

\subsection{Relocation of Events}

Two moderate earthquakes (M5.5 and M5.4) occurred in January 2010 near the town of Efpalio in the western part of Corinth Gulf, and that was the beginning of smaller magnitudes swarms that spread from Aigio to the west up to Rio-Antirrio strait, near the city of Patras. It was interesting to study the dense microseismic activity that appeared in this area for the period 2010-2011 and hence the relocation of the data was necessary in order to describe sufficiently the space-time distribution of the events. Since the 2010 events were relocated in a previous work (Karakostas et al., 2012), only the 2011 events were relocated here, using the computer program HYPOINVERSE

$\underline{\text { XLVII, No } 3-1110}$ 


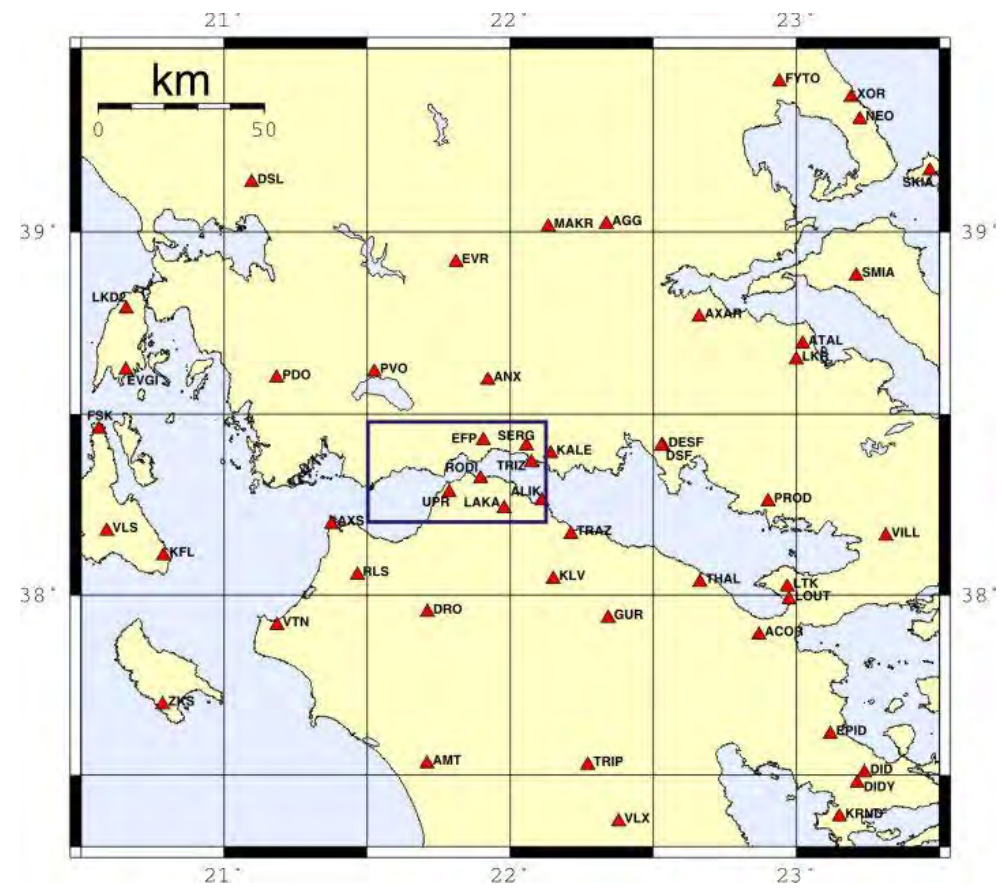

Figure 1 - Geographical distribution of the seismological stations of HUSN used in the present study. The study area is depicted by the rectangle.

(Klein, 2000) and, mainly, the one dimensional velocity model proposed for the area by Novotny et al. (2008). Because not only local seismological stations are used, one more layer added from the depth of $31 \mathrm{~km}$ with $\mathrm{P}_{\mathrm{n}}$-waves velocity equal to $\mathrm{v}_{\mathrm{n}}=7.9 \mathrm{~km} / \mathrm{s}$ (Panagiotopoulos and Papazachos, 1985), in the final velocity model given in (Table 1).

Table 1 - Crustal model used in this study for the hypocenter determination (Novotny et al., 2008; Panagiotopoulos and Papazachos, 1985).

\begin{tabular}{|c|c|}
\hline $\begin{array}{c}\text { P-wave velocity } \\
\text { (km/sec) }\end{array}$ & $\begin{array}{c}\text { Thickness } \\
\text { (km) }\end{array}$ \\
\hline 5.36 & 3.55 \\
\hline 5.37 & 3.10 \\
\hline 5.59 & 1.37 \\
\hline 5.97 & 2.20 \\
\hline 6.30 & 4.78 \\
\hline 6.5 & 15.3 \\
\hline 7.9 & $\infty$ \\
\hline
\end{tabular}

The mean value of velocity ratios $\left(\mathrm{v}_{\mathrm{p}} / \mathrm{v}_{\mathrm{s}}\right)$ was found equal to $1.81 \pm 0.06$ using the Wadati method for 141 earthquakes with seven or more S-arrivals. Previous studies in the western part of the Corinth Gulf (Rigo et al. 1996; Novotny et al. 2008; Pacchiani and Lyon Caen 2010) have shown a noteworthy variation in the values of velocity ratios that probably could be attributed to the complicated geological conditions and rheological changes. 


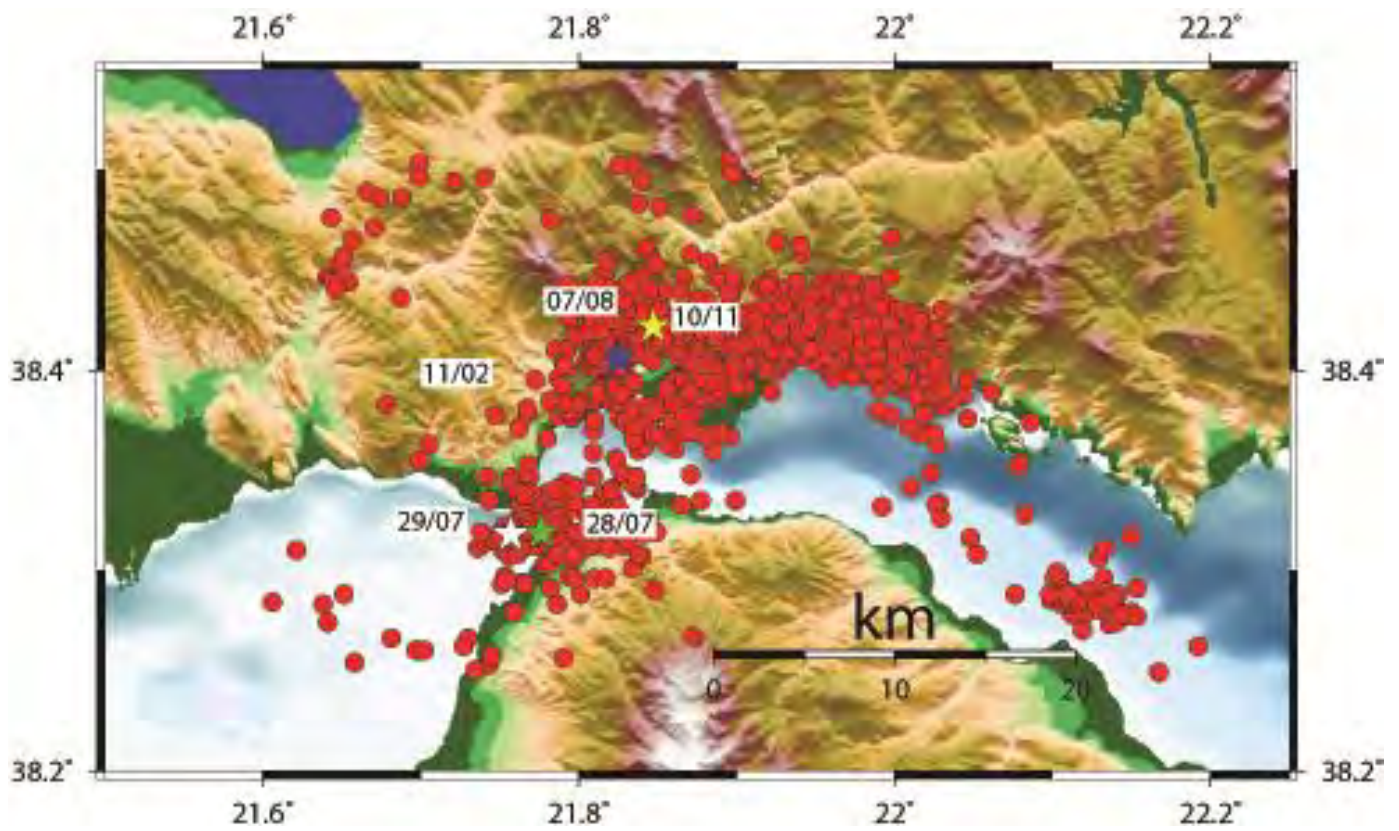

Figure 2 - Epicentral distribution of the relocated data set. The stars indicate the earthquakes with $M \geq 4.0$ occurred in 2011 .

Time corrections relative to the crustal model were calculated considering as origin time of each earthquake the one estimated from Wadati method. An iterative procedure (Karakostas et al., 2012) applied until the time corrections for all the stations to obtain a stable value. In fact, the procedure was repeated until the differences between the observed and the theoretical travel times to be $0.1 \mathrm{sec}$ or less in all stations used. For the relocation of the 365 shocks (Figure 2) the calculated time delays were taken into account. The average values for the estimated errors in origin time, epicenters and focal depths are $\mathrm{RMS}=0.12 \mathrm{sec}, \mathrm{ERH}=0.42 \mathrm{~km}$ and $\mathrm{ERZ}=1.09 \mathrm{~km}$, respectively.

\section{Fault Plane Solutions}

For the larger earthquakes of the data set of 365 events located in the study area we determined the fault plane solutions using the FPFIT Computer program (Reasenberg and Openheimer, 1985). The first step was to define manually the P-wave first onsets using only events with at least 10 impulse arrivals. For each fault plane solution, FPFIT calculates several uncertainty indices to characterize the quality of the final solution. The main indices are the misfit function $F_{j}$ which indicates the fit of the solution and can potentially range from 0 (for a perfect fit) to 1 (for a complete misfit), the station distribution ratio varying in the range 0 to 1.0 , as well as the uncertainties in strike, dip and rake of the final solution which for a reliable solution should be smaller than $20^{\circ}$. At this preliminary work we determined the focal mechanisms for 9 events for which we had adequate number (at least 10) of first onsets (Table 2, figure $3 \mathrm{~A}$ ) with mean misfit function $\mathrm{F}_{\mathrm{j}}$, equal to 0.19 , mean STDR equal to 0.6 and errors in strike, dip and rake smaller than $15^{\circ}$. Although there is a variety in the faulting type, where normal faulting coexist with thrust, the T axis (figure $3 \mathrm{~B}$ ) is found to be sub-horizontal and striking almost N-S to NNW-SSE in full agreement with the regional stress pattern. An adequate number of focal mechanisms provide the tool of revealing spatial variations of the stress field. 


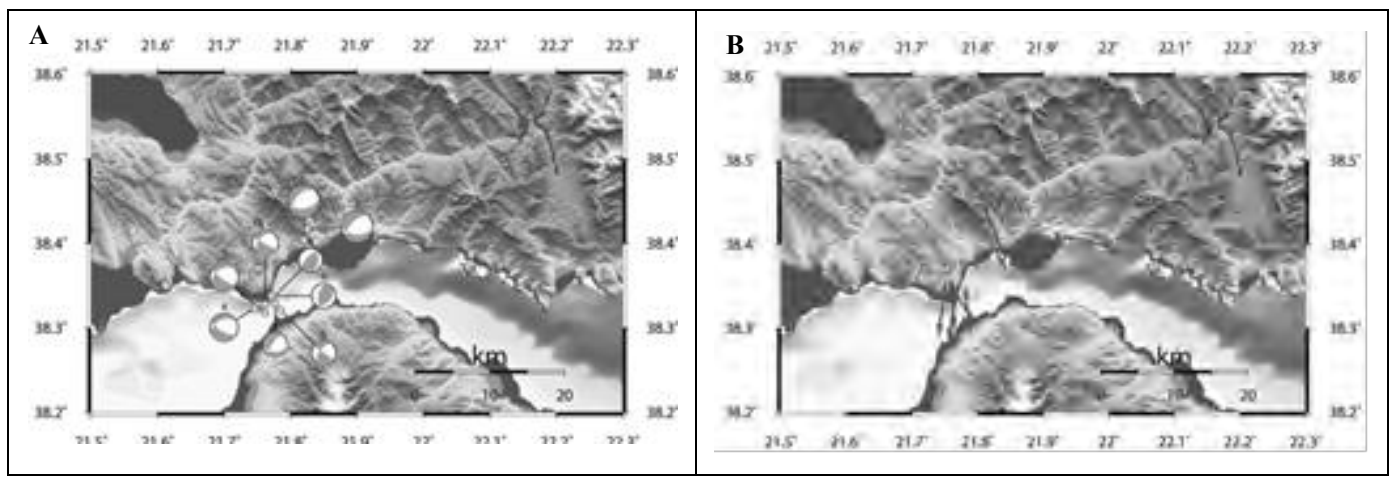

Figure 3 - A. Fault plane solution for selected earthquakes. The numbers correspond to the time order of earthquakes (Table 2) B. Horizontal projection of the $T$ axis for the same data set of focal mechanisms. The orientation of the vectors is mainly NNW-SSE in agreement with the regional stress field.

Table 2 - Fault plane solutions for the 9 earthquakes used in the present work. The strike, dip and rake correspond to the one nodal plane of the focal mechanism. The dip and azimuth of the $P$ - and $T$ - axis for each earthquake are given in last four columns.

\begin{tabular}{|c|c|c|c|c|c|c|c|c|c|c|c|c|c|}
\hline & \multicolumn{2}{|c|}{ Origin Time } & \multicolumn{2}{|c|}{ Epicenter } & \multirow[b]{2}{*}{ 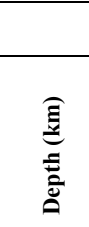 } & \multirow[b]{2}{*}{$\sum^{*}$} & \multicolumn{3}{|c|}{ Fault Plane Solution } & \multicolumn{2}{|c|}{ P-axis } & \multicolumn{2}{|c|}{ T-axis } \\
\hline$\stackrel{\pi}{\pi}$ & 气ิ๊ & $\stackrel{\mathscr{\Xi}}{\Xi}$ & $\underset{\Im}{\subsetneq}$ & $\underset{2}{\mathfrak{z}}$ & & & 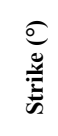 & $\begin{array}{l}\text { } \\
\stackrel{\sigma}{a}\end{array}$ & 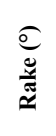 & 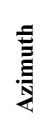 & 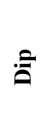 & $\underset{\mathrm{E}}{\stackrel{\Xi}{\mathrm{E}}}$ & 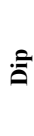 \\
\hline 1 & 24-Jul-2011 & 07:00:59.1 & 38.328 & 21.762 & 8.53 & 3.9 & 210 & 85 & -45 & 67 & 34 & 176 & 25 \\
\hline 2 & 28-Jul-2011 & 09:18:09.98 & 38.317 & 21.762 & 10.05 & 4.3 & 215 & 75 & -55 & 72 & 47 & 189 & 22 \\
\hline 3 & 29-Jul-2011 & $00: 26: 53.83$ & 38.329 & 21.777 & 9.5 & 3.7 & 185 & 40 & -35 & 81 & 53 & 327 & 16 \\
\hline 4 & 29-Jul-2011 & $19: 52: 26.28$ & 38.323 & 21.746 & 8.43 & 4.2 & 210 & 62 & -60 & 72 & 58 & 188 & 14 \\
\hline 5 & 7-Aug-2011 & $14: 35: 34.24$ & 38.404 & 21.820 & 9.713 .7 & 4.7 & 170 & 50 & -65 & 56 & 70 & 152 & 2 \\
\hline 6 & 14-Sep-2011 & $19: 20: 21.4$ & 38.321 & 21.785 & 8.11 & 3.7 & 35 & 90 & 30 & 75 & 19 & 173 & 21 \\
\hline 7 & 10-Nov-2011 & $17: 25: 39.82$ & 38.417 & 21.825 & 13.35 & 4.7 & 185 & 45 & -50 & 80 & 62 & 337 & 6 \\
\hline 8 & 26-Nov-2011 & $16: 41: 22.75$ & 38.336 & 21.774 & 12.14 & 3.6 & 95 & 35 & 55 & 299 & 14 & 175 & 65 \\
\hline 9 & 27-Nov-2011 & $15: 09: 13.36$ & 38.338 & 21.771 & 12.42 & 3.7 & 135 & 40 & 115 & 297 & 7 & 51 & 72 \\
\hline
\end{tabular}

\section{Space-Time Clustering of Seismicity}

\subsection{Space-Time Analysis}

To explore the evolution of seismic activity with time, a space-time plot in the NNE-SSW direction $\left(38.5^{\circ} \mathrm{N}-22.5^{\circ} \mathrm{E}\right.$ to $\left.38.2^{\circ} \mathrm{N}-21.65^{\circ} \mathrm{E}\right)$ is obtained according to the prevalent direction of the spatial distribution of the microearthquake activity (figure 4). Seismicity is started (0 day on the time axis) with the Efpalio earthquake in the central part of Corinth Gulf where two major earthquakes occurred, $M=5.5$ and four days later $M=5.4$ (Karakostas et al., 2012). As time advances ( $~ 100$ days) a migration of activity is observed in the western part of Corinth Gulf where a swarm of low magnitude earthquakes is appeared. The seismicity from this time forward until the end of 2010 is characterized from sparse microearthquakes without a specific bunch. Swarms are started to appear early in 2011 where an earthquake with magnitude $M=4.2$ occurred. After 
five months two clusters are shown in almost the same period. The first cluster is located in the southern part of the study area occupying a region with a length of $5 \mathrm{~km}$. Two moderate earthquakes $(M=4.2$ and $M=4.3)$ occurred here on 28 and 29 of July. After one month the second cluster is observed in the northern part of the study area where an earthquake of $M=4.7$ occurred. The length of this northern cluster is about $5 \mathrm{~km}$, almost equal to the previous one. The activity seems to continue in both the aforementioned clusters until the end of the year where an earthquake of $\mathrm{M}=4.7$ occurred in the northern cluster.

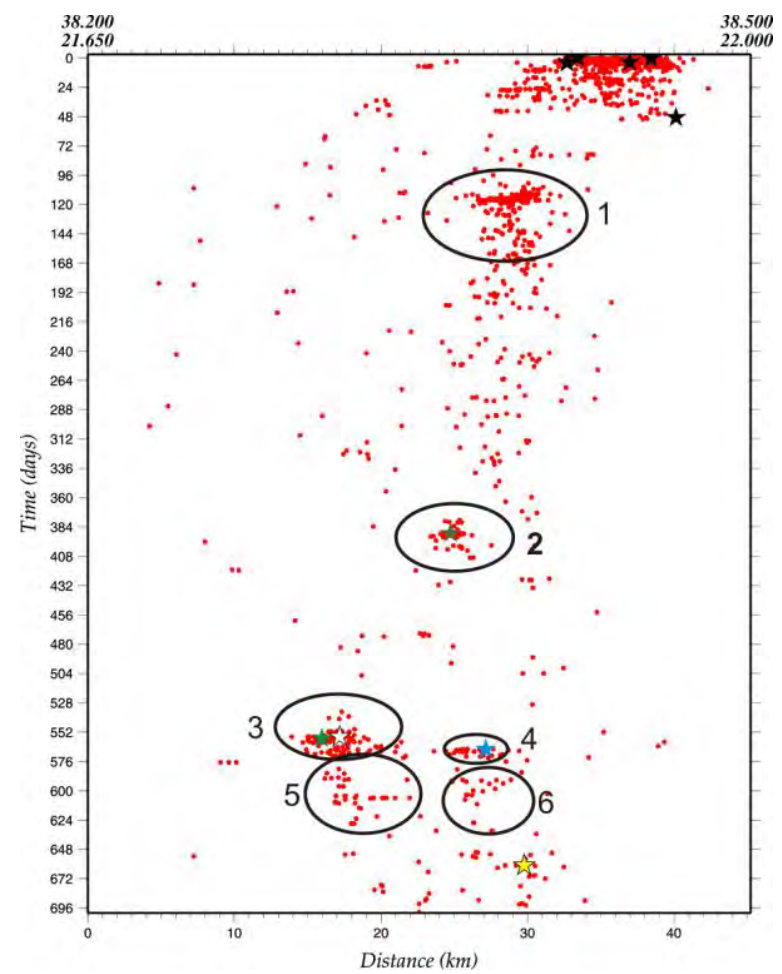

Figure 4 - Space time plot in the NNE-SSW direction of the seismicity distribution in the area under study. Coloured stars are same as in figure 2. Numbers indicate the time order of clusters.

\subsection{Discussion}

This paper deals with the characteristic seismicity that occurred in the western part of Corinth Gulf in 2011 after the 2010 seismic sequence of Efpalio. For this purpose 324 well-located events recorded by seismological stations in distances up to $140 \mathrm{~km}$ are used whereas these data enhanced using the 724 earthquakes from Efpalio seismic sequence. The distribution of relocated events (figure 2) indicates that the seismicity was spreading to the west forming two main clusters, in the northern part (as a continuation from the 2010 sequence) and in the southern part along the RioAntirrio strait. Generally the epicenters revealed an almost E-W striking seismic zone. The focal mechanisms (figure 3A, B) show that the orientation changes from ENE-WSW (northern cluster) to $\mathrm{E}-\mathrm{W}$ (southern cluster).

Aiming to seek for more details in the evolution of the swarms, space-time plots in different periods was performed (figure 5). It is evidenced that the events are concentrated in clusters and can be correlated with the earthquakes with $M \geq 4.0$ that occurred in the study area in 2011 . The increased seismicity along the Rio Antirrio strait is probably correlated to the fluids presence, as it is believed that fluids play an important role to the triggering of tectonic earthquakes (Nur and Booker 1972; Brodsky et al., 2000; Scholz, 2002; Prejean et al., 2004). 

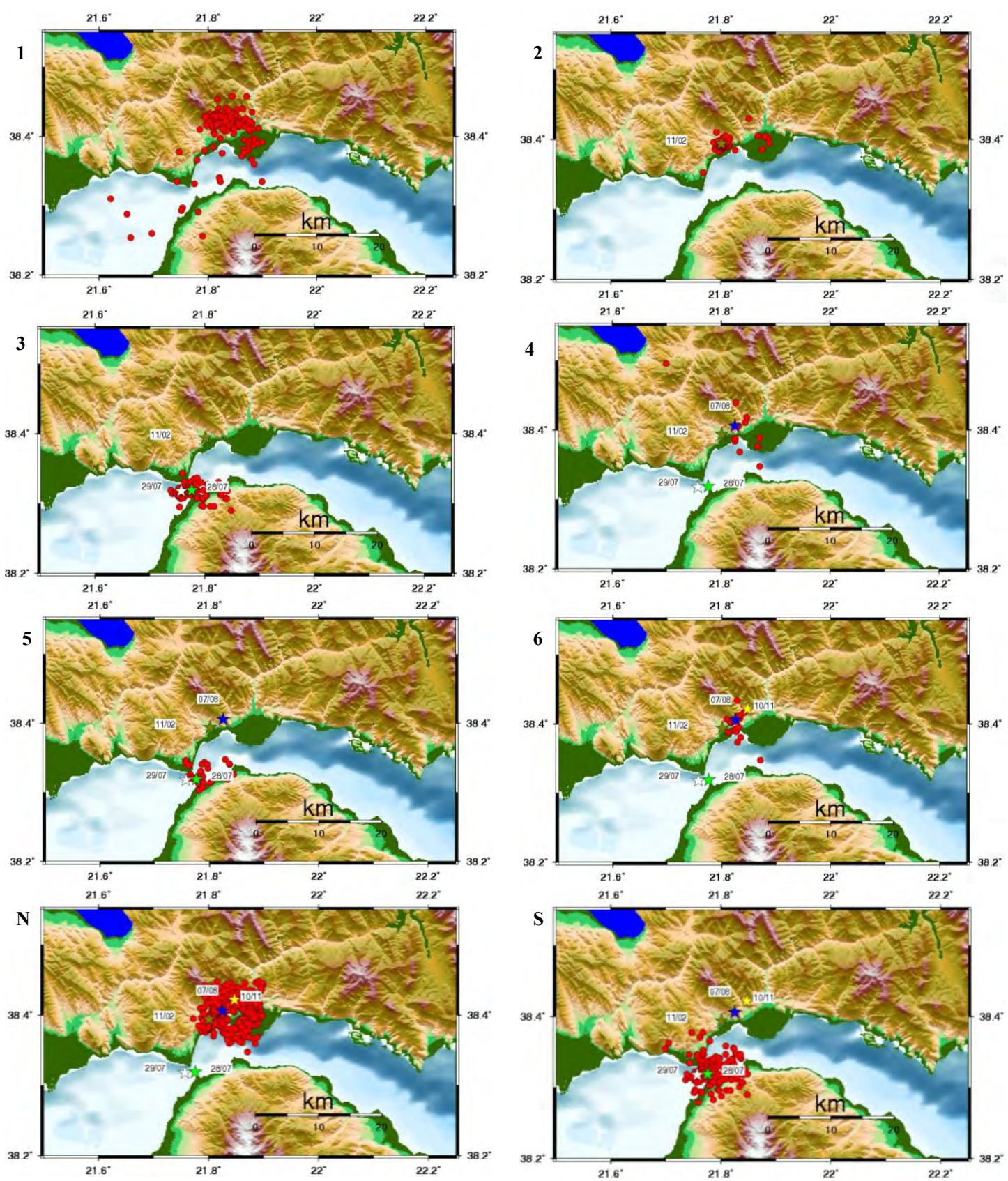

Figure 5 - Horizontal projection of seismic activity for the time period 2010-2011. Numbers (1 to 6) represent the seismic swarms that are referred in figure 4. The last two images (indicated as $\mathbf{N}$ and $\mathrm{S}$ ) obtain the space distribution of north and south clusters respectively. 


\section{Acknowledgments}

The GMT system (Wessel and Smith (1998) was used to plot the figures. We would like to thank the two anonymous reviewers for their comments and useful suggestions. Geophysics Department Contribution 809/2013.

\section{References}

Avallone A., Briole P., Agatza-Balodimou A.M., Billiris H., Charade O. and Veis G. 2004. Analysis of eleven years of deformation measured by GPS in the Corinth Rift Laboratory area, C.R.Geoscience, 336 (4-5):301-312.

Baker C., Hatzfeld D., Lyon-Caen H., Papadimitriou E. and Rigo A. 1997. Earthquake mechanisms of the Adriatic Sea and Western Greece: implications for the oceanic subductioncontinental collision transition, Geophys. J. Int., 131, 559-594.

Bell R.E., McNeill L.C., Bull J.M. and Hantstock T.J. 2008. Evolution of the western Gulf of Corinth, Bull. Geol. Soc. Am., 120(1/2), 156-178, doi:10.1130/B26212.1.

Briole P., Rigo A. Lyon-Caen H., Ruegg J.C., Papazissi,K. Mitsakaki C., Balodimou A., Veis G., Hatzfeld D. and Deschamps A. 2000. Active deformation of the Corinth rift, Greece: Results from repeated Global Positioning System surveys between 1990 and 1995, J. Geophys. Res., 105, 605-625.

Brodsky E.E., Karakostas V. and Kanamori H. 2000. A new observation of dynamically immerged regional seismicity: earthquakes in Greece following the August, 1999 Izmit, Turkey Earthquake, Geophys. Res. Lett., 27, 2741-2744.

Burton P.W., Xu Y., Qin CH., Tselentis G., Sokos E. 2004. A catalogue of seismicity in Greece and the adjacent areas for the twentieth century, Tectonophysics, 390, 117-127.

Doutsos T. and Poulimenos G. 1992. Geometry and kinematics of active faults and their seismotectonic significance in the western Corinth-Patras rift (Greece), Journal of Structural Geology, 14 (6), 689-699.

Flotte N., Sorel D., Muller C. and Tensi J. 2005. Along strike changes in the structural evolution over a brittle detachment fault example of the Pleistocene Corinth-Patras Rift (Greece), Tectonophysics, 403, 77-94.

Hatzfeld D., Pedotti G., Hatzidimitriou P. and Makropoulos K. 1990. The strain pattern in the western Hellenic arc deduced from a microearthquake survey, Geophys. J. Int., 101, 181202.

Hatzfeld D., Karakostas V., Ziazia M., Kassaras I., Papadimitriou E., Makropoulos K., Voulgaris N. and Papaioanou C. 2000. Microseismicity and faulting geometry in the Gulf of Corinth (Greece), Geophys. J. Int., 141, 438-456.

Hutton L.K. and Boore D.M. 1987. The $\mathrm{M}_{\mathrm{L}}$ scale in southern California, Bull. Seism. Soc. Am., 77, 2074-2094.

Karakostas V., Karagianni E. and Paradisopoulou P. 2012. Space-time Analysis, faulting and triggering of the 2010 earthquake doublet in western Corinth Gulf, Natural Hazard, doi:10.1007/s1 1069-012-0219-0.

Klein F.W. 2000. User's Guide to HYPOINVERSE-2000. A Fortran program to solve earthquake locations and magnitudes, U. S. Geol. Surv. Open File Report, 02-171 Version 1.0.

McNeil L.C., Cotterill C.J., Henstock T.J., Bull J.M., Stefanos A., Collier R.E.L., Papatheodorou G., Ferentinos G. and Hicks S.E. 2005. Active faulting within the offshore western Gulf of Corinth, Greece:Implication tops models of continental rift deformation, Geology, 33, 241 244.

Novotny O., Jansky J., Plicka V. and Lyon-Caen H. 2008. A layered model of the upper crust in the Aigio region of Greece, inferred from arrival times of the 2001 earthquake sequence, Stud. Geophys. Geod., 52, 123-131.

Nur A. and Booker J.R. 1972. Aftershocks caused by pore fluid flow? Science, 275, 885-887.

$\underline{\text { XLVII. No } 3-1116}$ 
Pacchiani F. and Lyon-Caen H. 2010. Geometry and spatio-temporal evolution of the 2001 Agios Ioanis earthquake swarm (Corinth Rift, Greece), Geophys. J. Int., 180, 59-72.

Panagiotopoulos D.G. and Papazachos B.C. 1985. Travel times of Pn waves in the Aegean and surrounding area, Geophys. J. R. astr. Soc., 80, 165-176.

Prejean S.G., Hill D.P., Brodsky E.E., Hough S.E., Johnston M.J.S., Malone S.D., Oppenheimer D.H., Pitt A.M. and Richards-Dinger K.B. 2004. Remotely triggered seismicity on the United States west coast following the $\mathrm{M}_{\mathrm{w}} 7.9$ Denali Fault earthquake, Bull. Seism. Soc. Am. 94(6B), S348-S359.

Reasenberg P. and Openheimer D. 1985. FPFIT, FPPLOT, and FPPAGE: FORTRAN computer programs for calculating and displaying earthquake fault-plane solutions, U.S. Geological Survey Open-File Report, 85-739.

Rigo A., Lyon-Caen H., Armijo R., Deschamps A., Hatzfeld D., Makropoulos K., Papadimitriou P. and Kassaras I. 1996. A micro-seismic study in the western part of the Gulf of Corinth (Greece): implications for large-scale normal faulting mechanisms, Geophys. J. Int., 126, 663-688.

Scholz C.H., 2002. The Mechanics of Earthquakes and Faulting, $2^{\text {nd }}$ Edn, Cambridge University Press, Cambridge.

Tselentis G-A. Serpetsidaki A. Martakis N. Sokos E. Paraskevopoulos P and Kapotas S. 2007. Local high resolution passive seismic tomography and Kohonen neural networks, application at the Rio-Antirrio Strait, Central Greece, Geophysics, Vol. 72, (4) 93-106.Wessel, P. and Smith, W. H. F., 1998. New, improved version of the Generic Mapping Tools Released, EOS Trans. $A G U, 79,579$. 